\title{
The effect of person-organization fit and hardiness on turnover intention among graduate trainee of a private palm oil enterprise in Indonesia
}

\author{
Kharina ${ }^{1 *}$, Zulkarnain ${ }^{2}$, Meutia Nauly ${ }^{3}$ \\ 1, 2, 3 Faculty of Psychology, University of North Sumatera, Medan, Indonesia
}

\section{Keywords \\ Turnover intention \\ Person-organization fit \\ Hardiness \\ Graduate trainee \\ Palm oil industry}

Received: 9 January 2018

Accepted: 17 January 2018

Published: 13 February 2018

\begin{abstract}
Turnover is a critical issue for companies because of its negative impact on companies, such as recruitment costs, training costs, low productivity, and operational disruption. The turnover intention has been acknowledged as the best predictor of actual turnover, hence, the importance of studying turnover intention. Most private palm oil enterprises in Indonesia offer trainee programs as their recruitment strategy for operational employees. Training programs are designed to help recruit fresh graduates to adapt to the company's culture and job role. Training programs are mostly 3-6 months in length and adapt semi-military concepts. Most of the trainees are reported to experience difficulty following the semi-military training and adapting to the company's culture due to misfit and incapability to handle stressful situations. This study aims to measure and analyze the effect of person-organization fit and hardiness on graduate trainee's turnover intention in one of Indonesia's Private Palm Oil Enterprises. This research uses a quantitative approach with multiple linear regression analysis methods. The sample size of this study is 103 graduate trainees who were taking part in the orientation training program within the enterprise. The result of the study indicates a negative influence of person-organization fit and hardiness on the turnover intention with an effective contribution of $62.4 \%$.
\end{abstract}

(c) 2018 The Author(s). Published by TAF Publishing.

\section{INTRODUCTION}

Agriculture is one of the key sectors of Indonesia's economy. One of Indonesia's important agricultural comodities is palm oil. Indonesia is currently the largest producer and exporter of palm oil worldwide. Palm oil cultivation in Indonesia is usually managed by either state or private enterprises. Driven by increased global demand and higher yields, palm oil cultivation in Indonesia has risen significantly (Food and Agriculture Organization, 2017). This condition has made business environment very competitive thus having competitive advantages is important for business sustainabilty. Competent and highly talented employees are the key assests for a company to achieve competitive advantages in business environment (Bernik, Azis, Kartini, \& Harsanto, 2015; Krisnawati, Perangin-Angin, Zainal, \& Suardi, 2016; Uren \& Jakson, 2012).
At the same time, companies are finding it increasingly difficult to find, hire and retain talent, which is also known as the War for Talent (Borngraber-Berthelsen, 2008). Many of the highly skilled employees are being attracted by more than one companies at the same time with various kinds of incentives such as better salary, promising career, and better job environment which eventually lead them to leave their current company, known as turnover (Augustine, 2011). Employee turnover is a critical problem for companies because of its negative consequences and associated costs that might affect companies's performance and productivity as a whole. Turnover can increase company's costs, such as replacement costs, recruitment process cost, lower productivity, decreasing organization's profits, potential loss of valuable knowledge, skills and also intellectual capital

* corresponding author: Kharina

†email: mei2ririn@hotmail.com 
(Atef, El-Leithy., \& Al-Kalyoubi, 2017; Hoai \& Thanwadee, 2015). Because of its negative consequences, numerous researches had been conducted to study the antecedents of turnover. One of the strongest predictors of actual turnover behavior is known as turnover intention (Kuean, Kaur, \& Wong, 2010), hence the importance of studying turnover intention.

This turnover phenomenon was also founded in one of Indonesia's private palm oil enterprises. As part of their recruitment strategy, this company offers trainee programs to their operational employees. Fresh graduates with certain majors and degrees are recruited straight out of the university. Recruited fresh graduates then begin their career within the company by following training programs. These training programs are designed to help the recruited fresh graduates to familiarize with the company's culture and their job role. Training programs are mostly 3-6 months in length, and adapt semi-military concepts. Recruited fresh graduates who follow training programs, are called graduate trainees. Training programs are divided into two terms: in class training and on the job training. In class training includes basic disicpline program and learning the theories and demonstration of materials, while on the job training includes "on fields" experiences for the positions. During training programs, trainees will be regularly evaluated and final evaluation of the training programs will decide trainees' status to be accepted as permanent employee or not.

Most of the trainees are reported to experience difficulty in following the semi-military training and adapting to the company's culture due to misfit and incapability to handle stressful situation. This situation later leads to trainees turnover in training programs. Highest trainees's turnover was recorded in year 2015 as $37.8 \%$. Kristof (1996) decribed the congruence between the values and norms of an organization with the values and norms of the employees working in an organization as person-organization fit. Many past researches had found the relationship between person-organization fit and turnover intention. Those studies show that employees who shared values and norms with their organization tended to stay longer in the company and employees who felt misfit with the organizations's values and norms are tended to leave the company (Giffen, 2015; Liu, Liu, \& Hu, 2010; MacArthur, 2012; Manirojana, 2016; Na Ayutthaya, Tuntivivat, \& Prasertsin, 2016; Peng, Lee, \& Tseng, 2014; Wen, Zhu, \& Liu, 2016).

Another factor that leads to trainees's turnover is their incapability to handle stressful situation during training programs. Kobasa (1979) described that an individual's personal characteristics acted as resistance resources that mediate the negative consequences of high level stress as hardiness. Past studies had found that employees with highly hardy attitudes showed the action pattern of coping with stressful circumstances by facing them and struggling to turn them from potential disaster into opportunities (Subramanian \& Vinothkumar, 2009). Furthermore, employees with high hardiness also had been found associated with higher positive organizational behavior such as job satisfaction, organization citizenship behavior, work engagement, and organizational commitment and lower negative organizational behavior such as perceived job stress, perceived job strain, abstenteeism, and turnover intention (Bal TaşTan, 2016; Cash, 2009; Cash \& Gardner, 2011; Ferreira, 2012; Garrosa, Ladstätter, Moreno, Gan, \& Carmona, 2014; Oetomo, Satrio, \& Lestariningsih, 2016; Vijayabanu, Govindarajan, \& Renganathan, 2014; Yanuardi \& Hadiwidjojo, 2014). This study aims to measure and analyze the effect of person-organization fit and hardiness on graduate trainees turnover intention in one of Indonesia's Private Palm Oil Enterprises.

\section{LITERATURE REVIEW}

\section{Turnover Intention}

Price (1977) defined turnover as the ratio of the number of organizational members who have left during the period being considered divided by the average number of people in that organization during the period. Employee turnover is a critical issue at both organizational and individual levels. Employee turnover can lead to the loss of talented employees, which might increase organizational cost (Liu et al., 2010) also damage organizational productivity and interruption in the organizational activities (Atef et al., 2017). Reviews on the antecedents of turnover intention have highlited intention to leave as an outcome variable. Turnover intention had been acknowledged as the best predictor of actual turnover. Therefore turnover intention has been studied as an alternative in measuring actual turnover. According to the Theory of Planned Behavior by Fishbein and Ajzen (1975), individual behavior is driven by behavior intention. This behavior intention concept proposes that individuals rationally reach a decision by systematically employing accesible information on the costs and benefits of the behavior and the control they have or believe they have, over carrying out. In order words behavior intentions are determined by attitudes towards the behavior, subjective norms and perceived behavior control. The measurement of intentions in the theory of planned behavior, can be defined in terms of its target, action, context 
and time element.

\section{Person-Organization Fit}

Chatman (1989) describes person-organization fit as the congruence between the norms and the values of organizations and persons. Meanwhile, Kristof (1996) described that person-organization fit happens when: (1) person and organization, at least either of them is able to provide the counterpart with required resources; (2) person and organization hold similarities in certain characteristics; (3) or both the conditions above are fulfilled. Person-organization fit has often been conceptualized in two different perspectives, first one is supplementary and complementary fit and the second is need-supplies and demand-abilities distinction. From these perspectives, Kristof (1996) identified four operationalizations of person-organization fit:

1) Value congruence which is described as similarity between fundamental characteristics of an individual and organizations such as value and personality.

2) Goal congruence which is described as similarity between individual's goal and organizational leaders, peers or organizational goal.

3) Employee need fulfillment which is described as similarity between individual preferences or needs and organizational system and structure.

4) Culture personality congruence which is described as similarity between the characteristics of individual personality and organizational climate.

Previous studies have demonstrated a negative effect of person-organization fit on turnover intention. Caldwell, Chatman, and O'Reilly (1990) found that person-organization fit was negatively associated with intention to quit for an accountant. Hoffman and Woehr (2006) also revealed that person-organization fit was related to turnover. A similar result was also shown by Jung and Yoon (2013) who found a negative relationship between person-organization fit and turnover intention. These studies have indicated that the individual and organizational "fit" increases the likelihood of the individual's willingness to stay with the organization.

\section{Hardiness}

Hardiness was first introduced by Kobasa (1979) who defined it as a pattern of personality characteristics that facilitates turning stressful circumstances from potential disaster into growth opportunities. According to Kobasa (1979), hardiness consisted of three components: Commitment, Control and Challenge.

1) Commitment is defined as a tendency to involve oneself in the activities in life and have genuine interest in and curiosity about the activities, things and other people (rather than sink into detachment and alienation).

2) Control is defined as a tendency to believe and act as if one can influence the life events through one's own effort (rather than feeling helpless).

3) Challenge is defined as the belief that changes in life (rather than stability) is the normative mode of life and see them as opportunities for personal growth.

Maddi (2002) suggested that hardiness acts as a protective factor in stressful situations predominantly through cognitive appraisal and coping behavior. He also explained that individuals high on hardiness tend to approach life demands more actively and perceive that they can handle them successfully which results in less stressful experience. Cash and Gardner (2011) also suggested that hardiness is positively related to job satisfaction and the use of adaptive coping strategies more frequently. Employees with high hardiness also had been found associated with higher work engagement, and organizational commitment and lower perceived job stress, perceived job strain, abstenteeism, and turnover intention (Bal TaşTan, 2016; Garrosa et al., 2014; Vijayabanu et al., 2014; Yanuardi \& Hadiwidjojo, 2014).

\section{Research Framework and Hypothesis}

Research framework of this study is shown in Figure 1. Therefore, the hypothesis of this study is personorganization fit and hardiness have a significant negative influence on turnover intention among graduate trainees.

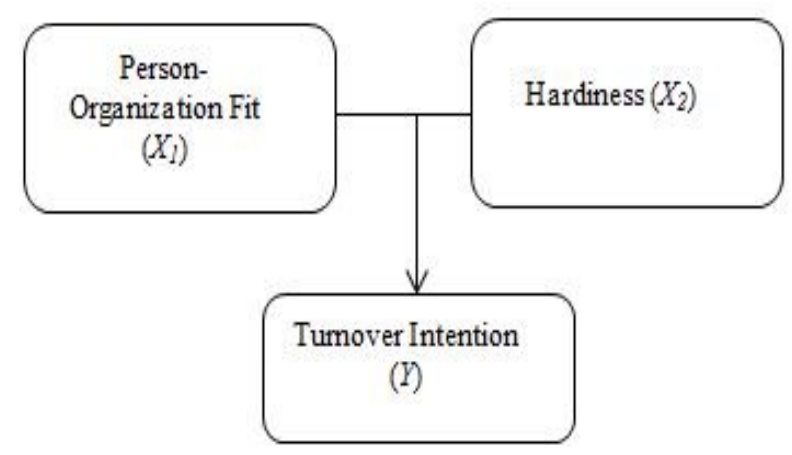

FIGURE 1. Conceptual framework

\section{METHODOLOGY}

\section{Participants}

This study used total sampling as sample collection technique, where all of the population becomes the research participants. Population for this study are 120 graduate trainees from year 2017. From 120 graduatee trainees only 103 can be selected as research participants due to incomplete data. All of research participants are male, 51\% (53) 
trainees are in class training, and 49\% (50) trainees are on the job training.

\section{Measurement Scales}

Main variables of this study are turnover intention, personorganization fit and hardiness. Quantitative approach by using a questionnaire for data collection is used in this study. Turnover intention was measured by adopting the intention aspect from Fishbein and Ajzen (1975), personorganization fit was measured by adopting the personorganization fit aspect from Kristof (1996) and hardiness was measured by adopting the hardiness aspect from Kobasa (1979). All questionnaires utilized a 5 point Likert type scale. A pilot study for ascertaining research instruments's reliability and validity was conducted. A total of 70 questionnaires was administered to a similiar sample but only 62 questionnaires were found useable for the pilot study. Questionnaires responses collected from the pilot study were then analyzed by using SPSS program. Reliability and principle component factor analysis with varimax rotation were performed for all three measurement scales. The total items for the questionnaires after the pilot study is 39 questions, divided into four sections. the first section is about personal information of the research participants, the second section is turnover intention scale which con- sists of 11 questions ( $\alpha=0.87$ ), the third section is personorganization fit scale which consists of 19 questions $(\alpha=$ 0.894) and the fourth section is hardiness scale which consists of 9 questions $(\alpha=0.865)$. Each questionnaire had a covering page explaining the purpose of the study, detailed instruction, and guarantee of confidentiality of each participant's data.

\section{Procedures}

Questionnaire was distributed to research participant by the assistance from company's representatives. Collected data from research participants were analyzed using SPSS program. Data were analyzed using descriptive statistics and multiple linear regression analysis methods. Data were also checked for multiple linear regression's basic assumptions (normality, linearity, multicollinearity, autocorrelation, and homoscedasticity).

\section{RESULTS}

\section{Basic Assumptions}

Normality

Multiple regressions assume that residuals are normally distributed (Jung \& Yoon, 2013). Normality in this study was checked through histograms of the standardized residuals. Figure 2 shows normality test for this study.

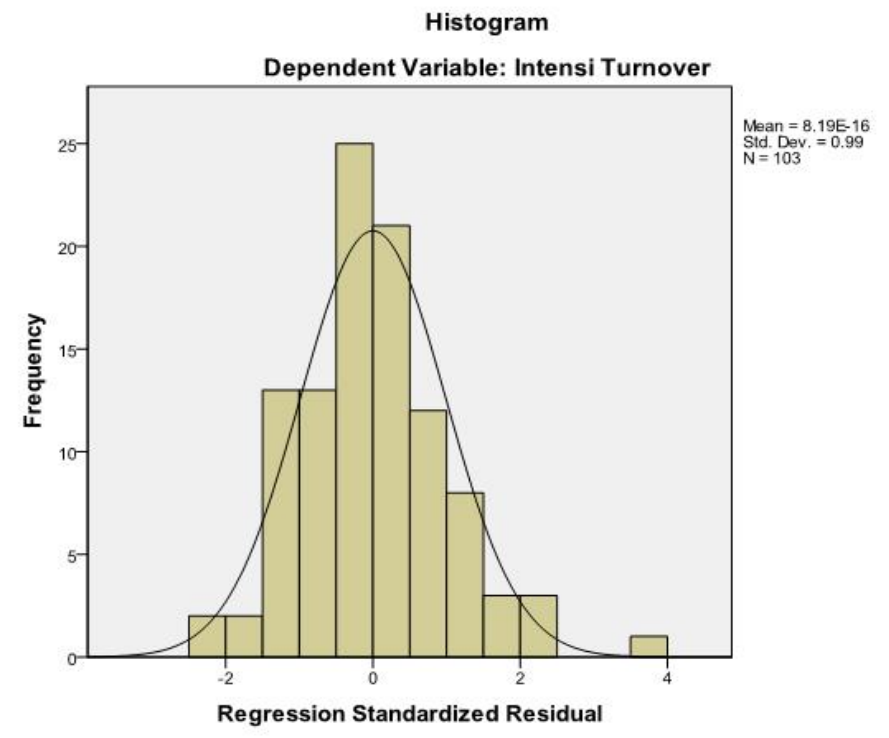

FIGURE 2. Normality test

\section{Linearity}

Multiple linear regression requires the relationship between the independent and the dependent variables to be linear. Linearity in this study was checked through statisti- cal analysis by using the test for linearity $p$-value must be < 0.05 to be concluded as linear. Table 1 shows linearity test for this study. 
TABLE 1. Linearity test

\begin{tabular}{lcl}
\hline \hline Variable & Linearity & Remarks \\
\hline Turnover intention * Hardiness & 0.000 & Linear \\
Turnover intention * Person organization & 0.000 & Linear \\
\hline \hline
\end{tabular}

\section{Autocorrelation}

Multiple linear regression requires that there is little or no autocorrelation in the data. Autocorrelation occurs when the residuals are not independent of each other. Autocorrelation in this study was checked through statistical analysis by using Durbin-Watson test and Run test to further check. Table 2 shows autocorrelation test using Durbin-Watson and Table 3 shows autocorrelation test using Run Test. Run test result shows $p$-value $>0.05$ which means data are free from autocorrelation.

TABLE 2. Autocorrelation test by Durbin-Watson

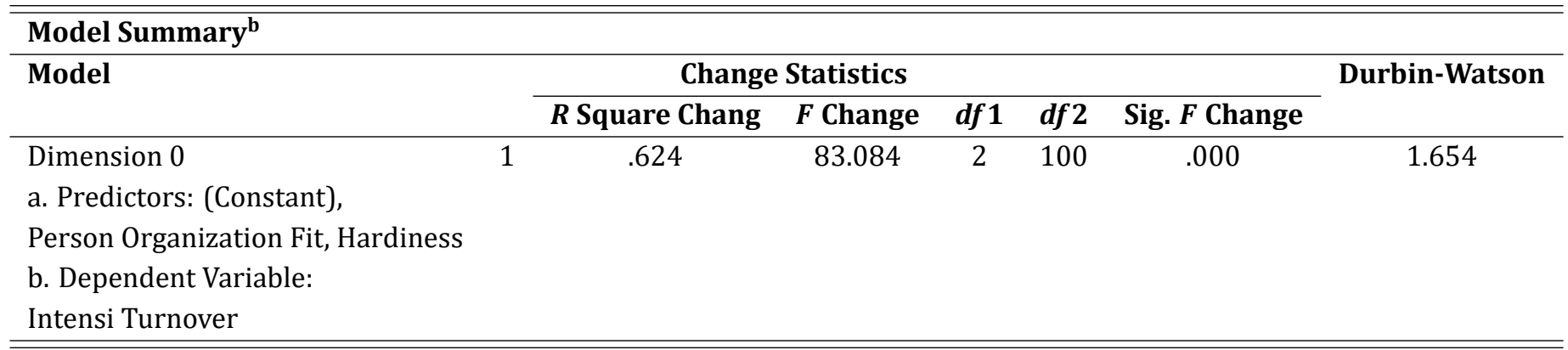

TABLE 3. Autocorrelation test by run test

\begin{tabular}{lc}
\hline \hline Runs Test & Unstandardized Residual \\
\hline Test value $^{\mathrm{a}}$ & -.27878 \\
Cases $<$ test value & 51 \\
Cases $>$ = test value & 52 \\
Total cases & 103 \\
Number of runs & 47 \\
$Z$ & -1.088 \\
Asymp. Sig. (2-tailed) & .276 \\
\hline \hline
\end{tabular}

a. Median

\section{Multicollinearity}

Multiple linear regression assumes that there is no multicollinearity in the data. Multicollinearity occurs when the independent variables are too highly correlated with each other. Multicollinearity in this study was checked through statistical analysis by using tolerance value and Variance Inflation Factor (VIF).

TABLE 4. Multicollinearity test

\begin{tabular}{llll}
\hline \hline Coefficients $^{\mathrm{a}}$ & & \\
\hline Model & & \multicolumn{2}{c}{ Collinearity Statistics } \\
\cline { 3 - 4 } & & Tolerance & VIF \\
\hline 1 & (Constant) & & \\
& Hardiness & .490 & 2.041 \\
& Person organization fit & .490 & 2.041 \\
a. Dependent variable: Intensi turnover & & & \\
\hline \hline
\end{tabular}


If tolerance value is $>0.1$ and $\mathrm{VIF}<10$, it is concluded that there is no multicollinearity. Table 4 shows multicollinearity test for this study.

\section{Homoscedasticity}

The assumption of homoscedasticity refers to equal variance of errors across all levels of the independent vari- ables. Multiple linear regression assumes that there is no heteroscedasticity. Homoscedasticity in this study was checked through statistical analysis by using Glejser test. If $p$-value $>0.05$ then it can be concluded that there is no heteroscedasticity. Table 5 shows heteroscedasticity test for this study.

TABLE 5. Heteroscedasticity test

\begin{tabular}{llcc}
\hline \hline \multicolumn{1}{l}{ Model } & $\boldsymbol{t}$ & Sig. \\
\hline 1 & (Constant) & 3.827 & .000 \\
& Hardiness & -1.209 & .229 \\
& Person organization fit & -.824 & .412 \\
\hline \hline
\end{tabular}

\section{Testing of Hypothesis}

The hyphotesis for this study states that there is a significant influence of person-organization fit and hardiness together on turnover intention. Multiple regression analysis by enter method was conducted to test this hypotesis. Table 6 provides the estimated coefficients of independent constructs and their significance values.

TABLE 6. Coefficient of estimators

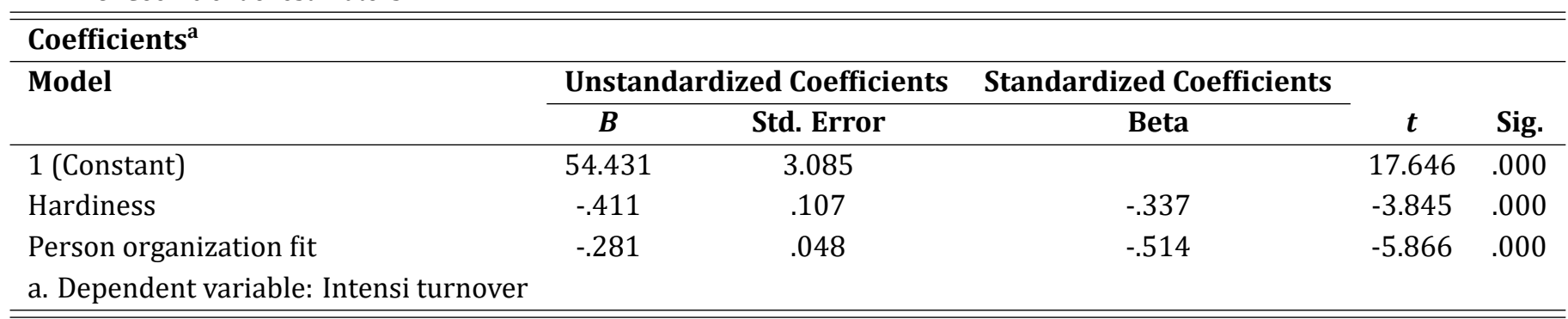

Hence, the multiple linear regression model is:

$T I=54.431-0.281 P O F-0.411 H$

Hypothesized relationships of person-organization fit and hardiness with turnover intention are supported from the derived model (negative influence). Next, Table 7 provides the effective contributions of person-organization fit and hardiness together towards turnover intention.

Empirical model has achieved $R$-square of $62.4 \%$ depicting that $62.4 \%$ of the variation of turnover intention is explained by person organization fit and hardiness.

TABLE 7. Model summary

\begin{tabular}{lcccc}
\hline \hline Model & $\boldsymbol{R}$ & $\boldsymbol{R}$ Square & Adjusted $\boldsymbol{R}$ Square & Std. Error of the Estimate \\
\hline Dimension0 1 & $.790^{\mathrm{a}}$ & .624 & .617 & 2.984 \\
\hline \hline
\end{tabular}

a. Predictors: (Constant), Person organization fit, Hardiness

TABLE 8. ANOVA

\begin{tabular}{lccccc}
\hline \hline Model & Sum of Squares & $\boldsymbol{D} \boldsymbol{f}$ & Mean Square & $\boldsymbol{f}$ & Sig. \\
\hline 1 Regression & 1479.489 & 2 & 739.744 & 83.084 & $.000^{\mathrm{a}}$ \\
Residual & 890.356 & 1008.904 & & & \\
Total & 2369.845 & 102 & & & \\
\hline \hline
\end{tabular}

a. Predictors: (Constant), Person organization fit, Hardiness

b. Dependent variable: Intensi turnover 
Further analysis by Analysis of Variance (ANOVA) was conducted to test the validity of the modelThe result in Table 8 showed $p$-value $=0.000$ which proved the validity of the model. This implies that person-organization fit and hardiness have an effect on turnover intention. These overall result then concluded that the hypothesis of the study was supported.

\section{DISCUSSION AND CONCLUSION}

Current study examines the influence of personorganization fit and hardiness on turnover intention among graduate trainees in one of Indonesia's private palm oil enterprises.The finding of this study indicates that there is a negative influence of person-organization fit and hardiness together towards turnover intention with effective contribution of $62.4 \%$ which supported hypothesis of the study. This implies if the person-organization fit and hardiness are high, the trainee will have lower intention to leave the company. This finding is in accordance with the earliest research, which indicated when employee has a higher congruence with organization's values, norms and goals they tend to stay longer in the organization (Giffen, 2015; Jung \& Yoon, 2013; Peng et al., 2014; Tugal \& Kilic, 2015; Wen et al., 2016) also when employees have high hardiness, they tend to adopt positive coping mechanism and show lower turnover intention (Bal TaşTan, 2016; Cash \& Gardner, 2011; Evendi \& Dwiyanti, 2013; Vijayabanu et al., 2014). Findings in this study could be explained by these reasons. First, is the recruitment strategy adopted by the company. In recruiting graduate trainee, company shows detailed information about company's profile as well as training programs and also the compensation benefits provided during and after graduating from the training program. Mayrhofer et al. (2005) stated that at the early stage of recruitment, applicant tends to make attribution towards company's values and perceives how well they will "fit in with those values. When applicant finds similarity between their personal values and company's value, they tend to find that company as the best place to have their career (Carless, 2005; Larsen \& Phillips, 2002; McCulloch \& Turban, 2007). Second, is the compensation management adopted by the company.
Compensation management is an integral part of human resource management which helps in designing appropriate compensation package, motivating employees and improving organizational effectiveness (Price Water House Coopers, 2014). In designing their compensation and benefit for the trainees, company attends to the yearly benchmarking with other companies from the same industry. This process enables the company to stay competitive within the market. Tugal and Kilic (2015) described that when employee's expectations and priorities are aligned with the facilities offered by the company, employees tend to stay longer and happier within the company. Third, trainees sees training programs as a challenge. Kobasa (1979) described that individuals with high hardiness tend to accept that life is by its nature stressful, and see those stressful changes as an opportunity to grow in wisdom and capability which can be turned to their advantage. They also see failures as the opportunities to learn for the future successes and feel that fulfillment can only be gained by having turned the stresses into growth opportunities. With this perspective, individual high on hardiness then tends to see things in positive perspectives and actively looks for an optimistic coping mechanism which results in lower job stress and decreased intention to leave the company (Maddi, 2002).

\section{LIMITATIONS AND RECOMMENDATIONS}

This study is not without limitations. Several limitations need to be noted when generalizing the results from this study: (1) This study was limited to studying the influence of person-organization fit and hardiness on turnover intention, other variables were not included in the study; (2) The collection of research data was conducted not directly by the researchers which caused incomplete data from some questionnaires; (3) This study used quantitative research methods to study the influence of person-organization fit and hardiness on turnover intention. In light of the limitations described above, recommendations for further studies are to study other variables besides the variables in this study, careful consideration for data collection and adoption of other research methods.

\section{REFERENCES}

Atef, G., El-Leithy., \& Al-Kalyoubi, M. (2017). Factor affecting employees turnover intention. International Business Management, 11(1), 118-130.

Augustine, H. (2011). Causes of employee turnover in micro finance institutions in Tanzania: The case study of presidential trust fund (Unpublished doctoral dissertation). The Open University of Tanzania, Dar es Salaam, Tanzania.

Bal TaşTan, S. (2016). Predicting job strain with psychological hardiness, organizational support, job control and work overload: An evaluation of Karasek's dcs model. Postmodern Openings/Deschideri Postmoderne, 7(1). doi:https:// 
doi.org/10.18662/po/2016.0701.07

Bernik, B., Azis, Y., Kartini, D., \& Harsanto, B. (2015). Managing innovation of smes in creative industry for interactive game subsector and TV and Radio subsector based on local wisdom in development of competitiveness business (case study SMEs in Bandung). International Journal of Business and Administrative Studies, 1(2), 49-53. doi:https://doi.org/ 10.20469/ijbas.10001-2

Borngraber-Berthelsen, M. (2008). Recruiting and retaining generation y: A new workforce (Unpublished doctoral dissertation). Aalborg University, Aalborg, Denmark.

Caldwell, D., Chatman, J., \& O'Reilly, C. (1990). Building organizational commitment: A multifirm study. Journal of Occupational and Organizational Psychology, 63(3), 245-261. doi:https://doi.org/10.1111/j.2044-8325.1990.tb00525.x

Carless, S. A. (2005). Person job fit versus person organization fit as predictors of organizational attraction and job acceptance intentions: A longitudinal study. Journal of Occupational and Organizational Psychology, 78(3), 411-429.

Cash, M. (2009). The impact of hardiness on organisational outcomes: Investigating appraisal and coping processes through alternative transactional models (Unpublished master thesis). The University of Auckland, Auckland, New Zealand.

Cash, M., \& Gardner, D. (2011). Cognitive hardiness, appraisal and coping: Comparing two transactional models. Journal of Managerial Psychology, 26(8), 646-664. doi:https://doi.org/10.1108/02683941111181752

Chatman, J. A. (1989). Improving interactional organizational research: A model of person-organization fit. Academy of management Review, 14(3), 333-349. doi:https://doi.org/10.5465/amr.1989.4279063

Evendi, R., \& Dwiyanti, R. (2013). Hubungan antara hardiness (kepribadian tahan banting) dengan intensi turnover pada karyawan pt sumber alfaria trijaya tbk di wilayah gombong kabupaten kebumen. Psychoidea, 11(2), 23-34.

Ferreira, N. (2012). Constructing a psychological career profile for staff retention (Unpublished doctoral dissertation). University of South Africa, Pretoria, South Africa.

Fishbein, M., \& Ajzen, I. (1975). Belief, attitude, intention and behavior: An introduction to theory and research. Reading, MA: Addison-Wesley.

Food and Agriculture Organization. (2017). Country fact sheet on food and agriculture policy trends. Retrieved from http:// goo.gl/SCdMrX (accessed April 21, 2017)

Garrosa, E., Ladstätter, F., Moreno, B., Gan, Y., \& Carmona, I. (2014). The experience of work engagement, hardy personality, optimism and subjective well-being among nurses from China and Spain. Open Journal of Social Sciences, 2(05), 106-112. doi:https://doi.org/10.1037/e572992012-367

Giffen, R. (2015). Organizational culture and personality type: Relationship with person-organization fit and turnover intention (Unpublished doctoral dissertation). State University, Ames, Iowa.

Hoai, N., \& Thanwadee, H. (2015). Investigating factors influencing profits enhancement in real estate companies in Ho Chi Minh City, Vietnam. International Journal of Business and Administrative Studies, 1(3), 107-113. doi:https://doi.org/ 10.20469/ijbas.10005-3

Hoffman, B. J., \& Woehr, D. J. (2006). A quantitative review of the relationship between person organization fit and behavioral outcomes. Journal of Vocational Behavior, 68(3), 389-399. doi:https://doi.org/10.1016/j.jvb.2005.08.003

Jung, H. S., \& Yoon, H. H. (2013). The effects of organizational service orientation on person organization fit and turnover intent. The Service Industries Journal, 33(1), 7-29. doi:https://doi.org/10.1080/02642069.2011.596932

Kobasa, S. C. (1979). Stressful life events, personality, and health: An inquiry into hardiness. Journal of Personality and Social Psychology, 37(1), 1-11. doi:https://doi.org/10.1037//0022-3514.37.1.1

Krisnawati, N., Perangin-Angin, L. K., Zainal, M., \& Suardi, I. (2016). Brand equity analysis and its impact on the loyal customer of local batik to develop its competitiveness (An empirical study of Batik Banten in South Tangerang). Journal of Administrative and Business Studies, 2(4), 189-207. doi:https://doi.org/10.20474/jabs-2.4.5

Kristof, A. L. (1996). Person-organization fit: An integrative review of its conceptualizations, measurement, and implications. Personnel Psychology, 49(1), 1-49. doi:https://doi.org/10.1111/j.1744-6570.1996.tb01790.x

Kuean, W., Kaur, S., \& Wong, E. (2010). Intention to quit: The malaysian companies perspectives. Journal of Applied Sciences, 10(19), 2251-2260. doi:https://doi.org/10.3923/jas.2010.2251.2260

Larsen, D. A., \& Phillips, J. I. (2002). Effect of recruiter on attraction to the firm: Implications of the elaboration likelihood model. Journal of Business and Psychology, 16(3), 347-364. doi:https://doi.org/10.1023/a:1012816822546 
Liu, B., Liu, J., \& Hu, J. (2010). Person-organization fit, job satisfaction, and turnover intention: An empirical study in the chinese public sector. Social Behavior and Personality: An International Journal, 38(5), 615-625. doi:https://doi.org/ 10.2224/sbp.2010.38.5.615

MacArthur, M. (2012). The association of person-environment fit and work-related attitudes for canadian forces personnel (Unpublished doctoral dissertion). Carleton University, Ottawa, Ontario.

Maddi, S. R. (2002). The story of hardiness: Twenty years of theorizing, research, and practice. Consulting Psychology Journal: Practice and Research, 54(3), 173-185. doi:https://doi.org/10.1037/1061-4087.54.3.175

Manirojana, P. (2016). The factors that affect the transparency and accountability of independent organizations in Thailand. Journal of Administrative and Business Studies, 2(5), 225-230. doi:https://doi.org/10.20474/jabs-2.5.2

Mayrhofer, W., Steyrer, J., Meyer, M., Strunk, G., Schiffinger, M., \& Iellatchitch, A. (2005). Graduates' career aspirations and individual characteristics. Human Resource Management Journal, 15(1), 38-56. doi:https://doi.org/10.1111/j.1748 -8583.2005.tb00139.x

McCulloch, M. C., \& Turban, D. B. (2007). Using person-organization fit to select employees for high-turnover jobs. International Journal of Selection and Assessment, 15(1), 63-71. doi:https://doi.org/10.1111/j.1468-2389.2007.00368.x

Na Ayutthaya, J., Tuntivivat, S., \& Prasertsin, U. (2016). The effect of positive psychological capital and organizational climate on service quality: The mediation role of work engagement of hotel service employees in Ratchaburi province. Journal of Administrative and Business Studies, 2(4), 167-176. doi:https://doi.org/10.20474/jabs-2.4.3

Oetomo, H. W., Satrio, B., \& Lestariningsih, M. (2016). The leadership style as moderating, influence of compensation, Organizational Citizenship Behaviour (OCB), and stress towards intention to quit. International Journal of Business and Economic Affairs, 1(1), 6-12. doi:https://doi.org/10.24088/ijbea-2016-11002

Peng, J.-C., Lee, Y.-L., \& Tseng, M.-M. (2014). Person--organization fit and turnover intention: Exploring the mediating effect of work engagement and the moderating effect of demand ability fit. Journal of Nursing Research, 22(1), 1-11. doi:https://doi.org/10.1097/jnr.0000000000000019

Price, J. L. (1977). The study of turnover. Ames, IA: Iowa State Press.

Price Water House Coopers. (2014). Annual report 2014-PwC UK. Retrieved from goo.gl/LuTNPY (accessed October 10, 2017)

Subramanian, S., \& Vinothkumar, M. (2009). Hardiness personality, self-esteem and occupational stress among it professionals. Journal of the Indian Academy of Applied Psychology, 35, 48-56. doi:https://doi.org/10.1007/s12646-012-0162-x

Tugal, F. N., \& Kilic, K. C. (2015). Person-organization fit: It's relationships with job attitudes and behaviors of Turkish academicians. International Review of Management and Marketing, 5(4), 195-202.

Uren, L., \& Jakson, R. (2012). What talent wants. Retrieved from http://goo.gl/fCuath (accessed April 24, 2016)

Vijayabanu, C., Govindarajan, K., \& Renganathan, R. (2014). Organizational citizenship behavior and job involvement of Indian private sector employees using visual PLS-SEM model. Management: Journal of Contemporary Management Issues, 19(2), 185-196. doi:https://doi.org/10.1179/1477963315z.00000000041

Wen, Y., Zhu, F., \& Liu, L. (2016). Person-organization fit and turnover intention: Professional identity as a moderator. Social Behavior and Personality: an international journal, 44(8), 1233-1242. doi:https://doi.org/10.2224/sbp.2016.44.8 .1233

Yanuardi, A., \& Hadiwidjojo, D. (2014). Faktor determinan atas profitabilitas perbankan yang terdaftar di bursa efek Indonesia. Jurnal Akuntansi Multiparadigma, 5(2), 202-218. doi:https://doi.org/10.18202/jamal.2014.08.5014 